\title{
Anti-metastatic effect of polysaccharide isolated from Colocasia esculenta is exerted through immunostimulation
}

\author{
HYE-RYUNG PARK ${ }^{1 *}$, HYUN-SUN LEE ${ }^{2 *}$, SUN YOUNG CHO ${ }^{1}$, YOON-SOOK KIM ${ }^{3}$ and KWANG-SOON SHIN ${ }^{1}$ \\ ${ }^{1}$ Department of Food Science and Biotechnology, Kyonggi University, Suwon-Si, Gyeonggi 443-760; ${ }^{2}$ Department of Food and \\ Nutrition, Korea University, Seoul 136-703; ${ }^{3}$ Korea Food Research Institute, Seongnam, Gyeonggi 463-746, Republic of Korea
}

Received June 14, 2012; Accepted November 15, 2012

DOI: $10.3892 /$ ijmm.2012.1224

\begin{abstract}
In the present study, an edible corm of the plant Colocasia esculenta, commonly known as Taro was extracted with cold water $\left(4^{\circ} \mathrm{C}\right)$. Finally, $10.44 \mathrm{~g}(1.04 \%)$ of the crude polysaccharide (Taro-0) was obtained from Taro. The purified active compound (Taro-4-I) was isolated using DEAE-Sepharose FF and Sephadex G-100. The anti-complementary activity of Taro-4-I $(57.3 \pm 4.5 \%)$ was similar to that of polysaccharide K (used as the positive control). The molecular weight of Taro-4-I was $200 \mathrm{kDa}$ and it was a polysaccharide composed of $64.4 \%$ neutral sugars and $35.6 \%$ uronic acid. Taro-4-I activated the complement system through the classical and alternative pathways. The treatment of peritoneal macrophages with Taro-4-I significantly increased the production of interleukin (IL)- 6 and tumor necrosis factor- $\alpha$ (TNF- $\alpha$ ) in a dose-dependent manner. However, IL-12 production showed maximal activity at $56 \mu \mathrm{g} /$ $\mathrm{ml}$ and subsequently decreased. Splenocytes obtained from mice which were administered Taro-4-I intravenously showed a higher toxicity to Yac-1 cells compared to those obtained from untreated mice in a effector-to-target $(\mathrm{E} / \mathrm{T})$ ratio-dependent manner. The group treated with $50 \mu \mathrm{g} / \mathrm{ml}$ Taro-4-I showed a significantly increased toxicity to Yac-1 cells compared to the group treated with $500 \mu \mathrm{g} / \mathrm{ml}$ Taro-4-I. The administration of Taro-4-I significantly inhibited the lung metastasis of B16BL6 melanoma cells. However, the group treated with $50 \mu \mathrm{g} / \mathrm{mouse}$ Taro-4-I had a significantly lower number of tumors compared to the group injected with $500 \mu \mathrm{g} /$ mouse Taro-4-I.
\end{abstract}

\section{Introduction}

It is well known that the majority of cancer-related deaths are not due to the primary tumor itself but to the dissemination of

Correspondence to: Professor Kwang-Soon Shin, Department of Food Science and Biotechnology, Kyonggi University, San 94-6, Iui-Dong, Yeongtong-Gu, Suwon-Si, Gyeonggi 443-760, Republic of Korea E-mail: ksshin@kyonggi.ac.kr

*Contributed equally

Key words: anti-metastasis, Colocasia esculenta, acidic polysaccharide, natural killer cell, anti-complementary tumor cells to secondary sites by a series of events collectively known as the metastatic cascade (1). Cancer metastasis, the spread of cancer cells from the primary neoplasm to distant sites and their growth there, is the major cause of mortality in patients with various types of cancer (2). Tumor invasion and metastasis involve multiple processes and various cytophysiological changes, including changed adhesion capability between cells and the extracellular matrix and damaged intercellular interactions (3). Most cancer treatments such as surgery, radiation therapy, or chemotherapy, usually attack not only cancer cells but normal cells as well, causing harmful side-effects (4). In recent years, a number of botanical compounds isolated from food or natural herbal medicines have been found to inhibit proliferation, induce apoptosis, suppress angiogenesis, retard metastasis and enhance chemotherapy, exhibiting anti-cancer potential in vitro and in vivo (5). While they possess anti-cancer properties, toxicity to normal tissues is rare (6).

Colocasia esculenta Linn. (C.esculenta) (family, Araceae) is an annual herbaceous plant with a long history of use in traditional medicine worldwide, particularly in tropical and subtropical regions. The edible corm of $C$. esculenta is commonly termed Taro, it is found throughout India and is also cultivated worldwide (7). Taro has been known since ancient times for its curative properties and has been utilized for the treatment of various ailments such as asthma, arthritis, diarrhea, internal hemorrhaging, as well as neurological and skin disorders (8). Brown et al (9) reported that the soluble extracts of a starchy paste made from Taro showed anti-proliferative activity against the rat YYT colon cancer cell line and activated the lymphocytes from splenocytes. However, they only used the soluble extracts of the starchy paste, without knowing the identity of the active compound. Therefore, the purpose of this study was to identify the active compound with immunostimulating activity in the edible corm of C.esculenta and elucidate the mechanisms by which it stimulates the immune system.

\section{Materials and methods}

Plant material. The edible corm of C. esculenta (Taro), which was cultivated in Gyeongbuk, Korea in 2009, was purchased from a commercial market. A voucher specimen was deposited at the Graduate School of Food Biotechnology, Kyonggi University, Gyeonggi, Korea. 
Isolation and purification of the polysaccharides from Taro. Taro $(1 \mathrm{~kg})$ was sliced and mixed with three volumes of distilled water and stirred at $4^{\circ} \mathrm{C}$ overnight. After centrifugation at $6,000 \mathrm{rpm}$ for $30 \mathrm{~min}$, the supernatant was precipitated with four volumes of ethanol, dialyzed and lyophilized. Finally, $10.4 \mathrm{~g}(1.04 \%)$ of crude polysaccharides were obtained. The crude polysaccharides were purified by ion exchange chromatography on a DEAE-Sepharose $\mathrm{FF}\left(\mathrm{Cl}^{-}\right.$form) column (GE Healthcare, Uppsala, Sweden) with a stepwise gradient of $\mathrm{NaCl}(0,0.05-2 \mathrm{M} \mathrm{NaCl})$. Each fraction was collected, dialyzed against tap water and freeze-dried. The active fraction, Taro-4, was eluted with $0.2 \mathrm{M} \mathrm{NaCl}$ and was further purified by size-exclusion chromatography on a Sephadex G-100 column (GE Healthcare) using $50 \mathrm{mM}$ ammonium formate buffer ( $\mathrm{pH}$ 5.5). High-performance size-exclusion chromatography (HPSEC) of Taro-4-I was performed on an high-performance liquid chromatography (HPLC)-9500 instrument (Young-Lin Co., Gyeonggi, Korea) equipped with a Superdex 75 GL column (GE Healthcare). A total of $10 \mu \mathrm{l}$ of each polysaccharide solution were analyzed using an isocratic mobile phase (50 mM ammonium formate buffer, $\mathrm{pH} 5.5)$ at a flow rate of $0.5 \mathrm{ml} / \mathrm{min}$ at room temperature. The molecular weights of the purified polysaccharides were estimated from a calibration curve constructed with standard pullulans (P-800, 400, 200, 100, 50, 20, 10 and 5; Showa Denko Co., Ltd., Tokyo, Japan).

General analytical methods. Total carbohydrate, uronic acid and protein were determined using phenol- $\mathrm{H}_{2} \mathrm{SO}_{4}(10)$, m-hydroxydiphenyl (11) and the Bradford method (12) with a protein assay kit, using galactose, galacturonic acid and bovine serum albumin as the respective standards. The sugar composition of the polysaccharide samples was determined by gas chromatography (GC) analysis of their alditol acetates. The samples were then hydrolyzed with $2 \mathrm{M}$ trifluoroacetic acid for $1.5 \mathrm{~h}$ at $121^{\circ} \mathrm{C}$, converted into the corresponding alditol acetates (13) and analyzed by $\mathrm{GC}$ at $60^{\circ} \mathrm{C}$ for $1 \mathrm{~min}, 60 \rightarrow 220^{\circ} \mathrm{C}$ $\left(30^{\circ} \mathrm{C} / \mathrm{min}\right), 220^{\circ} \mathrm{C}$ for $12 \mathrm{~min}, 220 \rightarrow 250^{\circ} \mathrm{C}\left(8^{\circ} \mathrm{C} / \mathrm{min}\right)$, and $250^{\circ} \mathrm{C}$ for $15 \mathrm{~min}$, using a GC (GC 6000 series; Young-Lin Co.) equipped with an SP-2380 (Supelco, Bellefonte, PA, USA) capillary column. The molar ratios were calculated from the peak areas and response factors using a flame ionization detector.

Anti-complementary activity assay. Anti-complementary activity was measured by the complement fixation test based on complement consumption and the degree of red blood cell lysis by residual complement (14). Normal human serum (NHS) was obtained from volunteer adults. A total of $50 \mu \mathrm{l}$ aliquots of exopolysaccharide of various concentrations $(100,500$ and $1,000 \mu \mathrm{g} / \mathrm{ml})$ were mixed with equal volumes of NHS and gelatin veronal-buffered saline $\left(\mathrm{GVB}^{2+}, \mathrm{pH} 7.4\right)$ containing $500 \mathrm{mM} \mathrm{Mg}{ }^{2+}$ and $150 \mathrm{mM} \mathrm{Ca}^{2+}$, respectively. The mixtures were pre-incubated at $37^{\circ} \mathrm{C}$ for $30 \mathrm{~min}$ and the residual total hemolytic complement $\left(\mathrm{TCH}_{50}\right)$ was determined using IgM hemolysin-sensitized sheep erythrocytes (EA cells, $1 \times 10^{8}$ cells $\left./ \mathrm{ml}\right)$. The NHS was incubated with water and $\mathrm{GVB}^{2+}$ to provide a control. The anti-complementary activity of the isolated polysaccharides is expressed as the percent inhibition of the control $\mathrm{TCH}_{50}$ polysaccharide K (PSK) (15) from
Coriolus versicolor. $\mathrm{TCH}_{50}(\%)=\mathrm{TCH}_{50}$ (control) $-\mathrm{TCH}_{50}$ (treated with sample)/ $\mathrm{TCH}_{50}$ (control).

Immunoelectrophoresis. Alternative activation of the $\mathrm{C} 3$ protein was examined using standard one- and two-dimensional immunoelectrophoresis methods. NHS was incubated with Taro-4-I and an equal volume of one of the following three solutions: i) $\mathrm{GVB}^{2+}$, ii) $10 \mathrm{mM}$ ethylene-glycol-bis- $(\beta$ aminoethylether)-N,N,N',N'-tetraacetic acid (EGTA) solution containing $2 \mathrm{mM} \mathrm{MgCl}$ in $\mathrm{GVB}^{2+}\left(\mathrm{Mg}^{2+}\right.$-EGTA-GVB), or iii) $10 \mathrm{mM}$ EDTA solution in $\mathrm{GVB}^{2+}$ (EDTA-GVB). The incubations were carried out at $37^{\circ} \mathrm{C}$ for $30 \mathrm{~min}$. The serum was then subjected to crossed immunoelectrophoresis to observe the C3 cleavage products (16). Shortly after the first run in barbital buffer ( $\mathrm{pH} 8.6$; ionic strength, 0.025 with $1 \%$ agarose), the second run was performed on a gel plate (layer thickness, $1.5 \mathrm{~mm}$ ) containing $0.5 \%$ anti-human C3 serum (Sigma Chemical Co, St. Louis, MO, USA) which recognizes both C3a and $\mathrm{C} 3 \mathrm{~b}$, at a potential gradient of $15 \mathrm{~mA} /$ plate for $15 \mathrm{~h}$. After electrophoresis, the plate was fixed and stained with $0.2 \%$ bromophenol blue in $\mathrm{MeOH}$ :water:acetic acid (5:4:1) (17).

Animals. Specific pathogen-free (SPF), 6-week-old female BALB/c mice were purchased from G-Bio Animal, Inc. (Seoul, Korea). The mice were maintained in a clean rack in an SPF room at Kyonggi University. Water and a diet of pellets were supplied ad libitum. All animals experiments were carried out according to the instructions of the Ethics Committee for Use of Experimental Animals at Kyonggi University (2011-003).

Macrophage proliferation and cytokine production. Peritoneal macrophages were harvested from thioglycollate-treated 6-week-old BALB/c mice as described previously (18). The cells (1x10\%/well) were suspended in complete RPMI-1640 medium and plated in 96-well culture plates. After $2 \mathrm{~h}$ of incubation in a $5 \%$ humidified $\mathrm{CO}_{2}$ incubator, non-adherent cells were removed by washing with $\mathrm{PBS}$ and the adherent macrophages were incubated with the indicated doses of Taro-4-I for $24 \mathrm{~h}$. Macrophage proliferation was assayed using the Cell Counting kit-8 (Dojindo Molecular Technologies, Gaithersburg, MD, USA) (19) and the concentrations of various cytokines in the medium were determined by enzyme-linked immunosorbent assay kits (Becton-Dickinson and Co., Franklin Lakes, NJ, USA) according to the manufacturer's instructions.

Natural killer (NK)-mediated cytotoxicity assay. Yac-1 is a Moloney murine leukemia virus-induced lymphoma that lacks the expression of MHC-I and is sensitive to lysis by NK cells (20). Therefore, NK-mediated cytotoxicity was determined in Yac-1 and primary cultured splenocytes from sample-treated animals (21). Briefly, three BALB/c mice/group were administered Taro-4-I intravenously (i.v.) (5, 50 and $500 \mu \mathrm{g} / \mathrm{mouse})$ and their splenocytes were harvested three days after treatment. Single-cell suspensions of splenocytes were added to the Yac-1 cells $\left(1 \times 10^{5}\right.$ cells $\left./ \mathrm{ml}\right)$ to obtain effector-to-target $(\mathrm{E} / \mathrm{T})$ cell ratios of 100:1, 50:1 and 25:1 in U-bottomed nine-well plates, after which the cultures were incubated for $6 \mathrm{~h}$. Following incubation, the culture supernatants (100 $\mu \mathrm{l} /$ well) were mixed with lactate dehydrogenase (LDH) solution (Promega Co., Madison, WI, USA) and the absorbance value of each well 

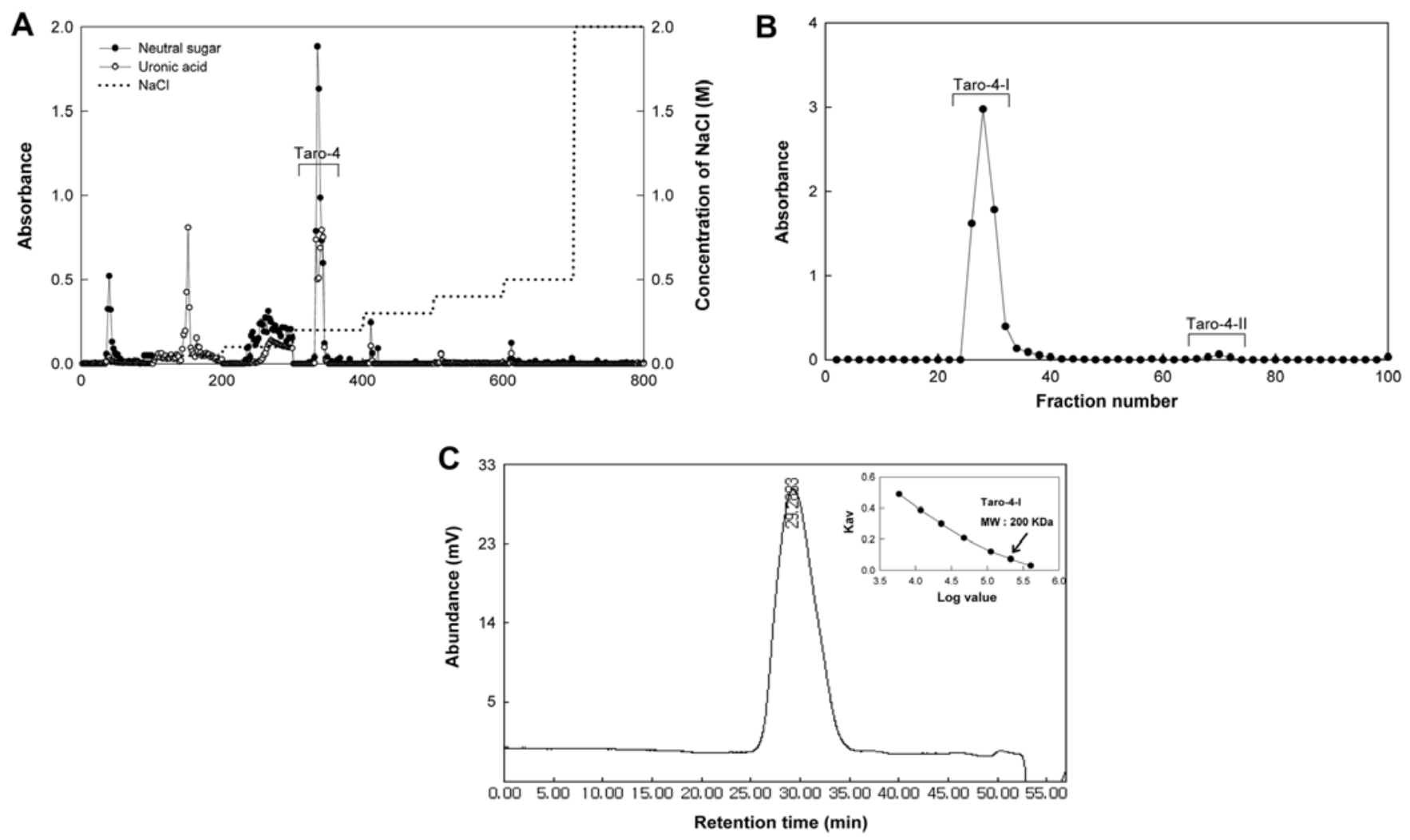

Figure 1. Purification steps of Taro-4-I from the edible corm of Colocasia esculenta. (A) Anion-exchange chromatography on DEAE-Sepharose FF (Cl- form) column with stepwise gradient of $\mathrm{NaCl}(0,0.05-2 \mathrm{M} \mathrm{NaCl})$. (B) Size exclusion chromatography on Sephadex G-100 or elution pattern of Taro-4 on Sephadex G-100. Taro-4 was subjected on a Sephadex G-100 column $(2.5 \times 90 \mathrm{~cm})$ and eluted with $50 \mathrm{mM}$ ammonium formate buffer $(\mathrm{pH} 5.5)$ at a flow rate of $0.2 \mathrm{ml} / \mathrm{min}$. (C) HPLC profile and molecular weight determination (in box) of Taro-4-I. HPLC equipped with Asahi-Pak GS-520 + GS-320 + GS-220 linked columns.

was measured at $490 \mathrm{~nm}$. The percentage of NK cellular cytotoxicity was calculated using the following formula: cytotoxicity $(\%)=[($ experimental release-spontaneous release $) /$ (maximum release-spontaneous release)] x100.

Anti-metastatic activity in vivo. Experimental lung metastasis was assessed by i.v. inoculation of B16BL6 melanoma cells $\left(2.7 \times 10^{4}\right.$ cell/mouse) into syngeneic BALB/c mice (22). Treatment with various Taro-4-I doses was carried out two days prior to or one day after i.v. inoculation with B16BL6 melanoma cells. The mice were sacrificed 14 days following tumor inoculation and their lungs were fixed in Bouin's solution. Lung tumor colonies were counted under a dissecting microscope.

Statistical analysis. All statistical analyses were performed using the Statistical Package for Social Sciences (SPSS) version 12.0 (SPSS Inc., Chicago, IL, USA). Differences among groups were evaluated by a one-way Analysis of variance (ANOVA) and Duncan's multiple range test. All data are presented as the means \pm standard deviation (SD).

\section{Results}

Purification of an active compound from C. esculenta with anti-complementary activity. The edible corm of $C$. esculenta was extracted with cold water $\left(4^{\circ} \mathrm{C}\right)$ and $10.44 \mathrm{~g}(1.04 \%)$ of the crude polysaccharide (Taro- 0 ) was obtained. The polysaccharide was then applied to column chromatography using
DEAE-Sepharose FF. Anti-complementary activities of subfractions from DEAE-Sepharose FF were detected in the following order: fraction eluted with $0.4 \mathrm{M} \mathrm{NaCl}$ (Taro-6) and fraction eluted with $0.3 \mathrm{M} \mathrm{NaCl}$ (Taro-5) $>$ fraction eluted with $0.5 \mathrm{M} \mathrm{NaCl}$ (Taro-7) $>$ fraction eluted with $0.2 \mathrm{M} \mathrm{NaCl}$ (Taro-4) $>$ fraction eluted with $1.0 \mathrm{M} \mathrm{NaCl}$ (Taro-3). The yield of Taro-4 (30.5\%) was higher than that of Taro-6 $(3.1 \%)$, Taro-5 (3.9\%) and Taro-7 (0.1\%). Therefore, we selected the Taro-4 fraction for the following purification step. When Taro-4 was applied to a Sephadex G-100 column, it was divided into two subfractions, Taro-4-I and Taro-4-II (Fig. 1B) and the Taro-4-I subfraction was found to exhibit higher anti-complementary activity, as shown in Table I. Taro-4-I showed a single peak on HPLC, indicating that this fraction was highly purified (Fig. 1C).

Characterization of purified compound having anticomplementary activity. The anti-complementary activity of Taro-4-I (57.3 $\pm 4.5 \%)$ was similar to that of PSK, which was used as the positive control (Table I). The molecular weight of Taro-4-I was $200 \mathrm{kDa}$ (Fig. 1C). Taro-4-I was a polysaccharide composed of $64.4 \%$ neutral sugars and $35.6 \%$ uronic acid. Taro-4-I mainly comprised of galactose (38.9 mole \%), mannose (19.2 mole \%) and glucose (4.2 mole \%) in the neutral sugar portion (Table II).

Activation mode of the complement system. The most important effector of the complement system, C3, is present in the human 
Table I. Purification procedure and yield of each fraction.

\begin{tabular}{|c|c|c|c|}
\hline Purification step & Recovery & Yield (\%) & $\begin{array}{l}\text { Anti-complementary activity } \\
\operatorname{ITCH}_{50}(\%)^{\mathrm{a}}\end{array}$ \\
\hline Colocasia esculenta & $1.0 \mathrm{~kg}$ & & \\
\hline Cold water extract & $10.4 \mathrm{~g}$ & 100.0 & $41.3 \pm 0.8^{\mathrm{d}}$ \\
\hline \multicolumn{4}{|l|}{ DEAE Sepharose FF } \\
\hline $0.00 \mathrm{M} \mathrm{NaCl}$ & $637 \mathrm{mg}$ & 6.1 & $30.8 \pm 3.4^{\mathrm{e}}$ \\
\hline $0.05 \mathrm{M} \mathrm{NaCl}$ & $1,936 \mathrm{mg}$ & 18.5 & $34.0 \pm 1.1^{\mathrm{e}}$ \\
\hline $0.10 \mathrm{M} \mathrm{NaCl}$ & $1,617 \mathrm{mg}$ & 15.5 & $43.1 \pm 1.0^{\mathrm{d}}$ \\
\hline $0.2 \mathrm{M} \mathrm{NaCl}$ (Taro-4) & $3,188 \mathrm{mg}$ & 30.5 & $55.8 \pm 3.1^{\mathrm{c}}$ \\
\hline $0.3 \mathrm{M} \mathrm{NaCl}$ & $410 \mathrm{mg}$ & 3.9 & $65.1 \pm 1.3^{\mathrm{a}}$ \\
\hline $0.4 \mathrm{M} \mathrm{NaCl}$ & $319 \mathrm{mg}$ & 3.1 & $66.4 \pm 0.4^{\mathrm{a}}$ \\
\hline $0.5 \mathrm{M} \mathrm{NaCl}$ & Trace & 0.1 & $61.7 \pm 1.6^{\mathrm{b}}$ \\
\hline $2 \mathrm{M} \mathrm{NaCl}$ & $273 \mathrm{mg}$ & 2.6 & $34.1 \pm 2.0^{\mathrm{e}}$ \\
\hline \multicolumn{4}{|l|}{ Sephadex G-100 } \\
\hline Taro-4-I & $2,060 \mathrm{mg}$ & 19.7 & $57.3 \pm 4.5^{\mathrm{c}}$ \\
\hline Taro-4-II & Trace & & \\
\hline
\end{tabular}

Table II. Chemical properties of the purified compound (Taro-4-I) from Colocasia esculenta.

\begin{tabular}{lc}
\hline Composition/component & $(\%)$ \\
\hline Chemical composition $^{\mathrm{a}}$ & \\
Neutral sugar & 64.4 \\
Uronic acid & 35.6 \\
Protein & 0.0 \\
Sugar component ${ }^{\mathrm{b}}$ & $(\text { Mole } \%)^{\mathrm{c}}$ \\
Rhamnose & 0.1 \\
Fucose & 0.0 \\
Arabinose & 1.7 \\
Xylose & 0.3 \\
Mannose & 19.2 \\
Galactose & 38.9 \\
Glucose & 4.2 \\
Galacturonic acid + glucuronic acid & 35.3 \\
\hline
\end{tabular}

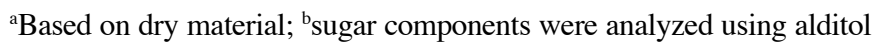
acetates by GC; ${ }^{c}$ mole \% calculated from the detected total carbohydrate.

plasma in large quantities $(800-1,800 \mu \mathrm{g} / \mathrm{ml})$ and it is converted to $\mathrm{C} 3 \mathrm{a}$ and $\mathrm{C} 3 \mathrm{~b}$ by cleavage, which is the major reaction in complement activation (23). Both $\mathrm{Mg}^{2+}$ and $\mathrm{Ca}^{2+}$ are required to activate the classical pathway, but only $\mathrm{Mg}^{2+}$ is required to activate the alternative pathway. Taro-4-I was used in different buffer systems to evaluate the complement activation pathway.
Under the $\mathrm{GVB}^{2+}$ experimental condition containing $\mathrm{Mg}^{2+}$ and $\mathrm{Ca}^{2+}$ ions, Taro-4-I cleaved C3 and exhibited a clear second precipitin line (C3a and $\mathrm{C} 3 \mathrm{~b}$ protein) (Fig. 2Aa). Additionally, under the $\mathrm{GVB}^{2+}$ experimental condition containing $\mathrm{Mg}^{2+}$, Taro-4-I exhibited a clear second precipitin line. Under the $\mathrm{GVB}^{2+}$ experimental condition containing $\mathrm{Mg}^{2+}$ and $\mathrm{Ca}^{2+}$, the detected anti-complementary activity was $\sim 50.5 \pm 4.5 \%$ at $1,000 \mu \mathrm{g} / \mathrm{ml}$ (Fig. 2B), which was the outcome of participation in both complement-activated pathways leading to cellular lysis. Furthermore, when anti-complementary activity was determined under the $\mathrm{Ca}^{2+}$-depleted experimental condition $\left(\mathrm{GVB}^{2+}\right.$ containing $\mathrm{Mg}^{2+}$ ) (Fig. 2Ab), which only acts on the alternative pathway, Taro-4-I cleaved C3 and exhibited a clear second precipitin line and the detected anti-complementary activity was $\sim 29.0 \pm 2.0 \%$ of the activity at $1,000 \mu \mathrm{g} / \mathrm{ml}$ (Fig. 2B). These results indicated that the mode of complement activation by Taro-4-I was via not only the classical, but also the alternative pathway, although to a lesser extent.

Effect of Taro-4-I on macrophage activation. We examined the Taro-4-I toxicity on primary cultured peritoneal macrophages by incubating the cells with doses up to $500 \mu \mathrm{g} / \mathrm{ml}$. Taro-4-I at the maximum dose did not affect cell viability compared to the control (Fig. 3A). Subsequently, the effect of Taro-4-I on various cytokines, such as interleukin (IL)-6, IL-12 and tumor necrosis factor (TNF)- $\alpha$, was assessed by incubating peritoneal macrophages with doses up to $500 \mu \mathrm{g} / \mathrm{ml}$. The treatment of peritoneal macrophages with Taro-4-I significantly increased the production of IL-6 (Fig. 3B) and TNF- $\alpha$ (Fig. 3D) in a dose-dependent manner. The production of IL-12 showed maximal activity at $56 \mu \mathrm{g} / \mathrm{ml}$, after which it declined (Fig. 3C). 
A

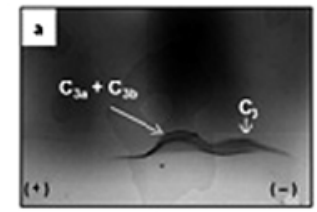

$\mathrm{GVB}^{2+}$ ( $\mathrm{Ca}^{2+}$ and $\mathrm{Mg}^{2+}$ ions)

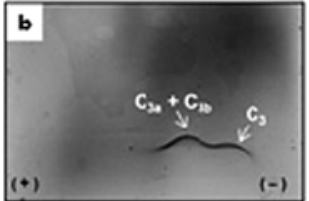

$\mathrm{Mg}^{2+} \cdot$ EGTA-GVB ${ }^{2-}$ ( $\mathrm{Mg}^{2+}$ ions only)

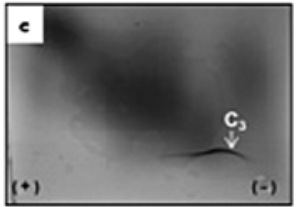

EGTA-GVB'-

B

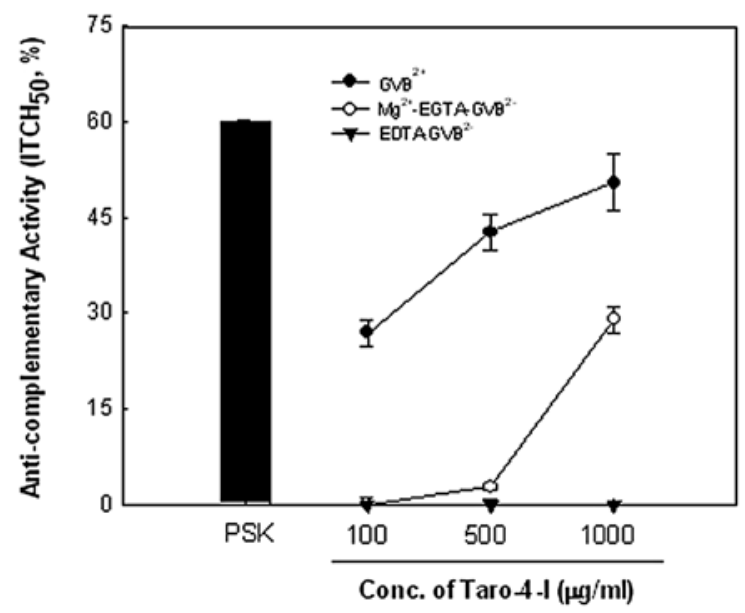

Figure 2. Alternative C3 fragmentation by Taro-4-I from the corms of Colocasia esculenta. (A) Image of immunoelectrophoresis with goat anti-human C3 antibody. (B) Anti-complementary activity with/without $\mathrm{Ca}^{2+}$ and $\mathrm{Mg}^{2+}$. Immunoelectrophoresis was carried out as described in detail in Materials and methods. Anti-complementary activity was presented as the inhibition of 50\% total complement hemolysis by Meyer's method. Polysaccharide K (PSK), a known immunoactive polysaccharide from Coriolus versicolor, was used as the positive control. Values are presented as the means $\pm \mathrm{SD}(\mathrm{n}=3)$. Conc., concentration.

A
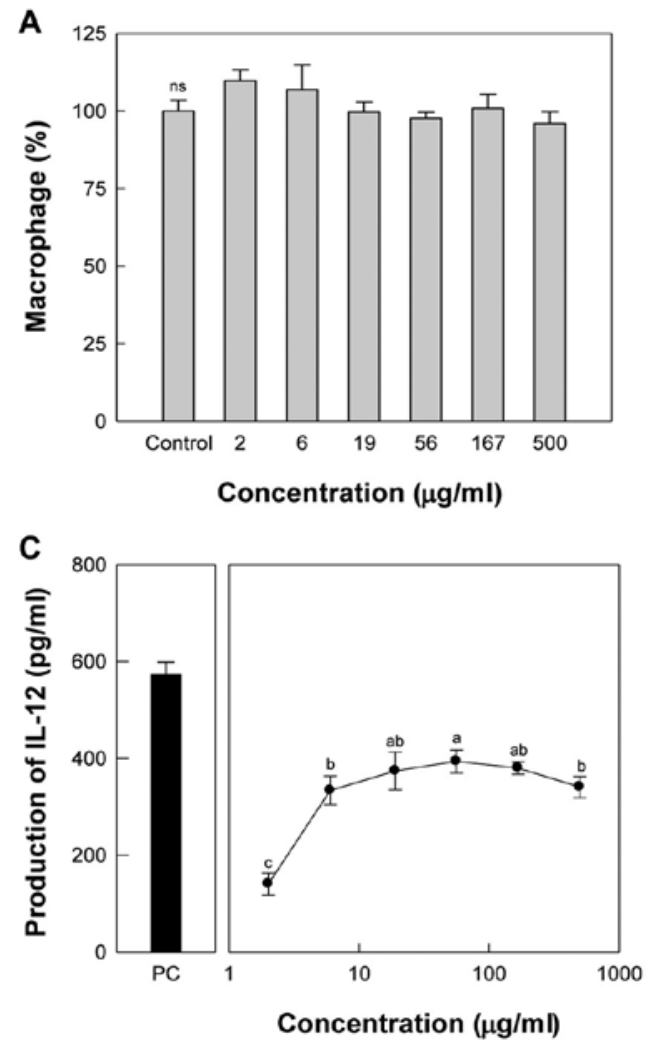
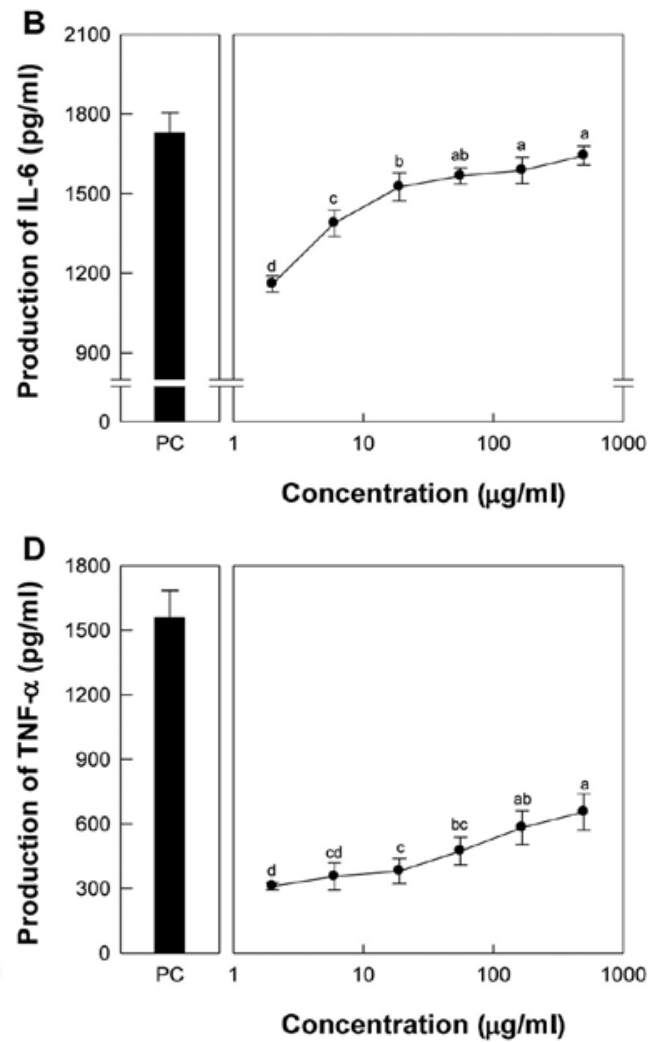

Figure 3. (A) Cytotoxic effect and production of cytokines including (B) IL-6, (C) IL-12 and (D) TNF- $\alpha$ by Taro-4-I in murine peritoneal macrophages. Peritoneal macrophages ( $1 \times 10^{6} /$ well) were treated with various concentrations of Taro-4-I in 96-well plates for $24 \mathrm{~h}$. Cytotoxicity was determined using the Cell Counting kit-8 (CCK-8) and the concentrations of various cytokines in the medium were determined by ELISA kits. A total of $5 \mu \mathrm{g} / \mathrm{ml}$ lipoploysacchoride (LPS) was used as the PC (positive control). Closed symbols (•) with lower case letters (a-d) indicate significant differences between groups $(\mathrm{P}<0.05)$ as shown by Duncan's multiple range tests. ns, not significant. 


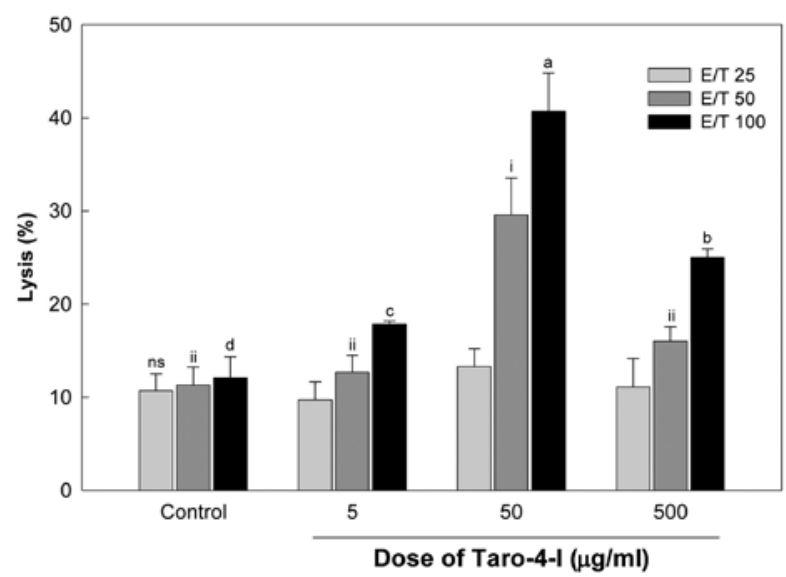

Figure 4. Effect of Taro-4-I on the activation of NK cells. NK-mediated cytotoxicity was determined in Yac-1 and primary cultured splenocytes from sample-treated animals. Folowing incubation, the culture supernatants were assayed with lactate dehydrogenase (LDH) content. Bars with lower case letters $(\mathrm{a}-\mathrm{d}$ or i-ii) indicate significant differences $(\mathrm{P}<0.05)$ as shown by Duncan's multiple range tests. ns, not significant.

Effect of Taro-4-I on NK cell activity. The effect of Taro-4-I on NK cell activity was estimated by the cytotoxic activity against Yac-1 cells, a NK-sensitive mouse lymphoma cell line, using an LDH release assay. Splenocytes obtained from mice administered with Taro-4-I showed a higher toxicity to Yac-1 cells compared to those obtained from untreated mice in a $E / T$ ratio-dependent manner (Fig. 4). The group treated with $50 \mu \mathrm{g} /$ $\mathrm{ml}$ Taro-4-I-showed a significantly higher toxicity to Yac-1 cells than the group treated with $500 \mu \mathrm{g} / \mathrm{ml}$ Taro-4-I.

Inhibitory effect of Taro-4-I on lung metastasis. We examined the effect of Taro-4-I on the experimental lung metastasis produced by B16BL6 melanoma cells. The administration of Taro-4-I significantly inhibited the lung metastasis of B16BL6 melanoma cells (Fig. 5). However, the group treated with $50 \mu \mathrm{g}$ /mouse Taro-4-I had a significantly lower number of tumors than the group treated with $500 \mu \mathrm{g} /$ mouse Taro-4-I.

\section{Discussion}

The innate immune system is phylogenetically older than the acquired (adaptive) or specific immune system and provides rapid but incomplete host defense until the slower, more definitive, acquired immune response develops (24). The complement system is an essential component of innate immunity and also plays an important role in modulating adaptive immunity (25). The complement system is a key component of the innate immune system, playing a central role in host defense against pathogens or cancer (26).
A

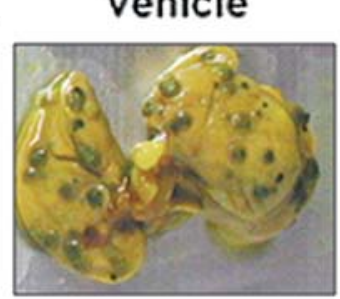

$5 \mu \mathrm{g} /$ mouse

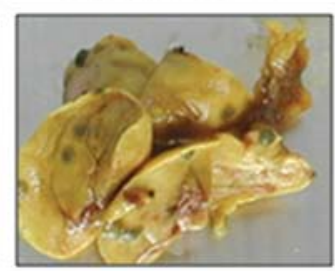

$50 \mu \mathrm{g} / \mathrm{mouse}$

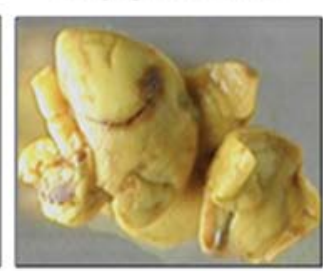

$500 \mu \mathrm{g} / \mathrm{mouse}$

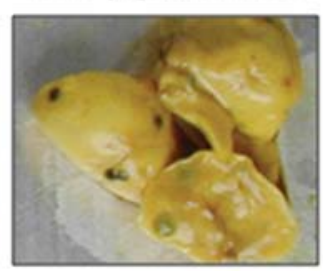

B

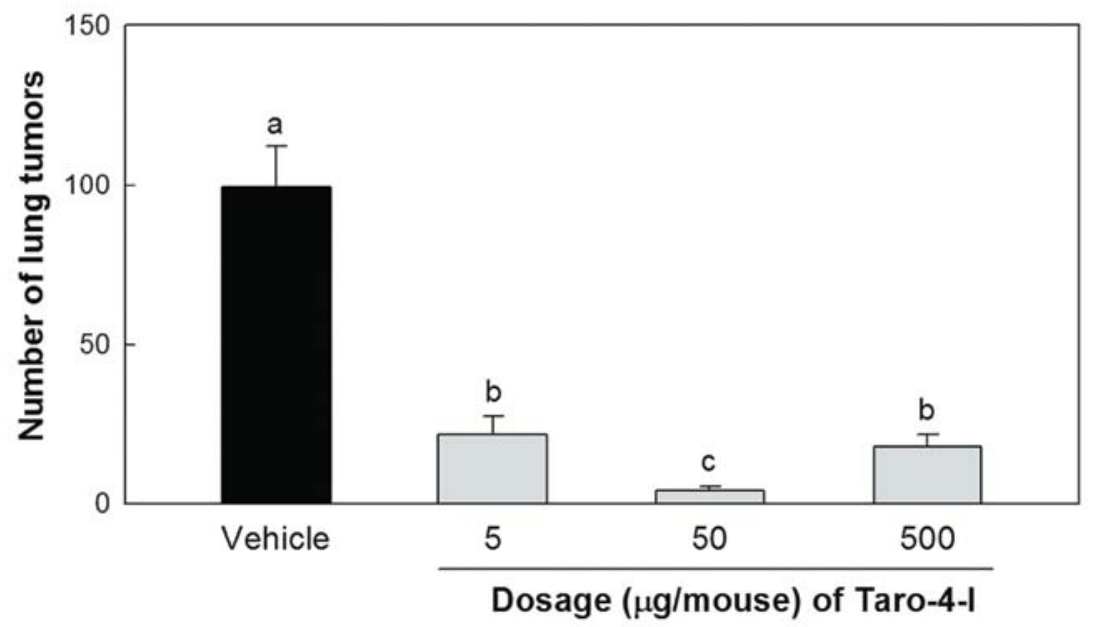

Figure 5. Anti-metastatic effect of Taro-4-I isolated from the corms of Colocasia esculenta on lung metastasis produced by i.v. inoculation of B16BL6 melanoma cells. (A) Scanned images of mouse lungs produced by i.v. inoculation of B16BL6 melanoma cells. (B) Five BALB/c mice per group were inoculated i.v. with 4x10 ${ }^{4}$ B16BL6 melanoma cells and injected i.v. with the indicated doses of Taro-4-I suspended in PBS two days prior to tumor inoculation. Mice were sacrificed 14 days after tumor inoculation for the evaluation of tumors. Bars with lower case letters (a-d) indicate significant differences $(\mathrm{P}<0.05)$ as shown by Duncan's multiple range tests. 
Research of food-derived bioactive components for cancer prevention and cancer therapy is expanding due to the relatively low or undetected toxicity (27) and better bioavailability of these components. Over the last three decades, polysaccharides isolated from botanical sources (mushrooms, algae, lichens and higher plants) have also attracted a great deal of attention in the biomedical arena, due to their broad-spectrum therapeutic properties (28) and relatively low toxicity. The most promising biopharmacological activities of these biopolymers are their immunomodulatory and anti-cancer effects (29). Three antitumor mushroom polysaccharides, lentinan, schizophyllan and protein-bound PSK (Krestin), isolated from Lentinus edodes, Schizophyllum commune and Coriolus versicolor, respectively, have become major commercial items in Japan (29). Although the mechanism of their antitumor action is not yet completely understood, these polysaccharides and polysaccharide-protein complexes have been shown to enhance cell-mediated immune responses in vivo and in vitro and act as biological response modifiers (BRMs). BRMs are considered a useful tool in tumor growth suppression and inhibition of metastasis.

In this study, we identified and purified a potentially novel therapeutic compound (Taro-4-I), derived from Taro. This compound is a polysaccharide containing 35.6\% uronic acid and is mainly comprised of galactose (38.9 mole\%), mannose (19.2 mole\%) and glucose (4.2 mole\%) with a molecular weight of $200 \mathrm{kDa}$ (Fig. 1C). The molecular weights of most immunostimulating polysaccharides are in the range of 6-1,000 kDa (30) and Taro-4-I falls within this range.

Anti-complementary activity is measured by the complement fixation test (14) and is expressed as the percentage inhibition of the control $\mathrm{TCH}_{50}$ PSK (15) from Coriolus versicolor as a positive control. The antitumor activity of PSK has been evaluated in Japan for the prevention of esophageal, gastric and lung cancers in humans with promising results and is even sold as a drug (29). The polysaccharide has been found to be well-tolerated and compatible with chemotherapy and radiation therapy. However, the mechanism of action of PSK is not yet completely understood. Animals administered PSK have shown increased neutrophil levels with concomitant toxicity of target cells and a marked decrease in size and number of metastatic lung foci (31). Torisu et al (32) evaluated the clinical efficacy and the mechanism of action of PSK using a randomized double-blind trial in 111 patients who underwent surgery for colorectal cancer. They reported that the survival rate of patients was significantly higher $(\mathrm{P}<0.05)$ in the PSK group than in the control group and the polymorphonuclear leukocytes from PSK-treated patients showed remarkable enhancement in their activities, such as random and/or chemotactic locomotion and phagocytic activity, when compared with those in the control group. In this study, the anticomplementary activity of Taro-4-I $(57.3 \pm 4.5 \%)$ was found to be similar to that of PSK $(60.0 \pm 0.0 \%)$ (Table I). Taro-4-I activated the complement system via the classical and alternative pathways (Fig. 2). The complement system plays an important role in host defense, inflammation and allergic reactions and is activated via the classical and alternative pathways. The classical pathway is activated by an immune complex containing IgM and IgG antibodies, the acute phase protein, C-reactive protein and RNA tumor viruses. The alternative pathway does not require antibodies and is directly activated by polysac- charides, certain immunoglobulins, viruses, fungi, bacteria, certain animal cells and parasites.

Macrophages are ancient and phylogenetically conserved cells found in all multicellular organisms and they, together with neutrophils, represent the first line of host defense after the epithelial barrier. Macrophages participate both in non-specific defense (innate immunity) and in the initiation of specific defense mechanisms (adaptive immunity) in vertebrate animals. The production of IL-12 in a co-incubation system of peritoneal macrophages with Taro-4-I showed maximal activity at $56 \mu \mathrm{g} / \mathrm{ml}$ (Fig. 3C). The group treated with $50 \mu \mathrm{g} / \mathrm{ml}$ Taro-4-I showed a significantly higher toxicity to Yac-1 cells, a NK-sensitive mouse lymphoma cell line, compared to the group treated with $500 \mu \mathrm{g} / \mathrm{ml}$ Taro-4-I (Fig. 4). The group treated with $50 \mu \mathrm{g} / \mathrm{mouse}$ Taro-4-I had a significantly lower number of tumors compared to the group treated with $500 \mu \mathrm{g} /$ mouse Taro-4-I (Fig. 5). IL-12 is produced mainly by macrophages and is a NK cell stimulatory factor. NK cell cytotoxicity may represent a way to eliminate overstimulated macrophages. NK cells are lymphocytes of the innate immune system that are involved in early defense against both allogeneic (non-self) cells and autologous cells undergoing various forms of stress, such as infection (with viruses, bacteria, or parasites) and malignant transformation (33). In vitro studies using cells from humans and several other mammalian species, as well as in vivo studies using mice and rats, have suggested that tumor cells are recognized as NK cell targets (34). It is thus speculated that Taro-4-I stimulates the complementary system and induces the secretion of various cytokines, such as IL-6, IL-12 and TNF- $\alpha$ from macrophages. The NK cells activated by IL-12 inhibit tumor metastasis.

The anti-cancer activity of the polysaccharides from Taro has previously been reported by Brown et al (9). However, this is the first study to demonstrate the anti-metastatic activity of the active compound isolated from Taro. Our data provide a scientific foundation for the anti-cancer and anti-metastatic activity of Taro-4-I, demonstrating that it exerts its effects through immunostimulation. The group treated with $50 \mu \mathrm{g} /$ mouse Taro-4-I showed remarkable preventive activity $(96.2 \pm 1.3 \%)$.

Based on our data, the administration of $\sim 162.5 \mathrm{mg} /$ day of Taro-4-I or $824.85 \mathrm{mg} /$ day of the cold water extract would be expected to have an anti-metastastic effect in humans (65 kg body weight) as calculated by the FDA dose calculator program. However, the anti-metastatic activity of Taro-4-I showed a bell-shaped profile. Its molecular weight is approximately $200 \mathrm{kDa}$. It is therefore questionable whether the whole structure is required for its anti-metastatic effects. Therefore, in future studies, we aim to further explore the optimal range for clinical trials and identify the essential structure.

\section{Acknowledgements}

This study was supported by the Technology Development Program of Ministry of Food, Agriculture, Forestry and Fisheries, Republic of Korea.

\section{References}

1. Liotta LA, Steeg PS and Stetler-Stevenson WG: Cancer metastasis and angiogenesis: an imbalance of positive and negative regulation. Cell 64: 327-336, 1991. 
2. Weiss L: Metastatic inefficiency. Adv Cancer Res 54: 159-211, 1990.

3. Chambers AF, Groom AC and MacDonald IC: Dissemination and growth of cancer cells in metastatic sites. Nat Rev Cancer 2: 563-572, 2002

4. Han SS, Cho CK, Lee YW and Yoo HS: Antimetastatic and immunomodulating effect of water extracts from various mushrooms. J Acupunct Meridian Stud 2: 218-227, 2009.

5. Tan W, Lu J, Huang M, et al: Anti-cancer natural products isolated from Chinese medicinal herbs. Chin Med 6: 27-42, 2011.

6. Harada M, Seta K, Ito O, et al: Concomitant immunity against tumor development is enhanced by the oral administration of a kampo medicine, Hochu-ekki-to (TJ-41: Bu-Zhong-Yi-Qi-Tang). Immunopharmacol Immunotoxicol 17: 687-703, 1995

7. Sheth AK: The Herbs of Ayurveda. A.K. Sheth Publishers, Ahmedabad, 2005.

8. Prajapati R, Kalariya M, Umbarkar R, et al: Colocasia esculenta: a potent indigenous plant. Int J Nutr Pharmacol Neurol Dis 1 : 90-96, 2011.

9. Brown AC, Reitzenstein JE, Liu J, et al: The anti-cancer effects of poi (Colocasia esculenta) on colonic adenocarcinoma cells in vitro. Phytother Res 19: 767-771, 2005.

10. Dubois M, Gilles K, Hamilton JK, et al: A colorimetric method for the determination of sugars. Nature 168: 167, 1951.

11. Blumenkrantz N and Asboe-Hansen G: New method for quantitative determination of uronic acids. Anal Biochem 54: 484-489, 1973.

12. Bradford MM: A rapid and sensitive method for the quantitation of microgram quantities of protein utilizing the principle of protein-dye binding. Anal Biochem 72: 248-254, 1976.

13. Jones TM and Albersheim P: A gas chromatographic method for the determination of aldose and uronic acid constituents of plant cell wall polysaccharides. Plant Physiol 49: 926-936, 1972.

14. Kabat EA and Mayer MM (eds): Complement and complement fixation. In: Experimental Immunochemistry. 2nd edition. Charles C. Thomas, Springfield, IL, pp133-240, 1971.

15. Saito H, Tomioka $\mathrm{H}$ and Sato K: PSK, a polysaccharide from Coriolus vesicolor, enhances oxygen metabolism of murine peritoneal macrophages and the host resistance to listerial infection. J Gen Microbiol 134: 1029-1035, 1988.

16. Shimura K, Ito H and Hibasami H: Screening of host-mediated antitumor polysaccharides by crossed immunoelectrophoresis using fresh human serum. Jpn J Pharmacol 33: 403-408, 1983.

17. Cyong JC, Witkin SS, Rieger B, et al: Antibody-independent complement activation by myelin via the classical complement pathway. J Exp Med 155: 587-598, 1982.

18. Saiki I, Saito S, Fujita C, et al: Induction of tumoricidal macrophages and production of cytokines by synthetic muramyl dipeptide analogues. Vaccine 6: 238-244, 1988.
19. Kim YH, Park JH,Lee M, et al: Polyethylenimine with acid-labile linkages as a biodegradable gene carrier. J Control Release 103: 209-219, 2005.

20. Kiessling R, Klein E and Wigzell $\mathrm{H}$ : Natural killer cells in the mouse. I. Cytotoxic cells with specificity for mouse Moloney leukemia cells. Specificity and distribution according to genotype. Eur J Immunol 5: 112-117, 1975.

21. Yoon TJ, Yoo YC, Kang TB, et al: Prophylactic effect of Korean mistletoe (Viscum album coloratum) extract on tumor metastasis is mediated by enhancement of NK cell activity. Int J Immunopharmacol 20: 163-172, 1998.

22. Yoo YC, Saiki I, Sato K and Azuma I: MDP-Lys(L18), a lipophilic derivative of muramyl dipeptide, inhibits the metastasis of haematogenous and non-haematogenous tumours in mice. Vaccine 12: 175-180, 1994.

23. Platts-Mills TA and Ishizaka K: Activation of the alternative pathway of human complement by rabbit cells. J Immunol 113 348-358, 1974.

24. Fearon DT and Locksley RM: The instructive role of innate immunity in the acquired immune response. Science 272: 50-53, 1996.

25. Zhu H, Di H, Zhang Y, Zhang J, et al: A protein-bound polysaccharide from the stem bark of Eucommia ulmoides and its anti-complementary effect. Carbohydr Res 344: 1319-1324, 2009.

26. Frank MM and Fries LF: The role of complement in inflammation and phagocytosis. Immunol Today 12: 322-326, 1991.

27. Wasser SP: Medicinal mushrooms as a source of antitumor and immunomodulating polysaccharides. Appl Microbiol Biotechnol 60: 258-274, 2002.

28. Paulsen BS: Plant polysaccharides with immunostimulatory activities. Curr Org Chem 5: 939-950, 2001.

29. Ooi VE and Liu F: Immunomodulation and anti-cancer activity of polysaccharide-protein complexes. Curr Med Chem 7: 715-729, 2000.

30. Kweon MH, Hwang HJ and Sung HC: Isolation and characterization of anticomplementary beta-glucans from the shoots of bamboo Phyllostachys edulis. Planta Med 69: 56-62, 2003.

31. Tzianabos AO: Polysaccharide immunomudulators as therapeutic agents: structural aspects and biologic function. Clin Microbiol Rev 13: 523-533, 2000.

32. Torisu M, Hayashi Y, Ishimitsu T, et al: Significant prolongation of disease-free period gained by oral polysaccharide K (PSK) administration after curative surgical operation of colorectal cancer. Cancer Immunol Immunother 31: 261-268, 1990.

33. Vivier E, Nunes JA and Vely F: Natural killer cell signaling pathways. Science 306: 1517-1519, 2004

34. van Dommelen SLH, Sumaria N, Schreiber RD, et al: Perforin and granzymes have stinct roles in defensive immunity and immunopathology. Immunity 25: 835-848, 2006. 